\title{
Testing controlled productive knowledge of adverb-verb collocations in junior researchers using English as a foreign language
}

\author{
Déogratias Nizonkiza \\ North-West University (Potchefstroom Campus), School of Languages, Potchefstroom, South Africa | McGill \\ Writing Centre, McGill University, Canada \\ E-mail: deo.nizonkiza@nwu.ac.za
}

\section{Kris Van De Poel}

University of Antwerp, Department of Linguistics, Antwerpen, Belgium | North-West University (Potchefstroom Campus), School of Languages, South Africa

E-mail: kris.vandepoel@uantwerpen.be

\begin{abstract}
The present study examines English as a Foreign Language (EFL) junior researchers' use of adverbverb collocations of academic vocabulary in both free-written and controlled productions. A small corpus was compiled and analysed in order to identify verbs in adverb-verb combinations and examine which ones were collocated correctly or erroneously. A controlled productive test of adverb-verb collocations, with verbs selected from the Academic Word List (Coxhead 2000) and adverbs selected from Crowther, Dignen and Lea's (2002) Oxford collocations dictionary for students of English was also administered to participants. Results indicate that free-productive knowledge of adverb-verb collocations is challenging for EFL users. This finding supports previous studies that focused mainly on verb-noun collocations, and that reached the conclusion that EFL students are not sensitive enough to collocations to use them in their written productions (cf. Nesselhauf 2005). This finding is extended here to adverb-verb collocations. The study also reveals that controlled productive knowledge of adverbverb collocations is less problematic. Based on these results, teaching strategies aimed at improving the use of adverb-verb collocations among EFL users are proposed.
\end{abstract}

Key words: academic writing, adverb-verb collocations, productive knowledge of collocations, English as a Foreign Language (EFL), Academic Word List (AWL)

\section{Introduction}

Given their widely accepted importance in second/foreign language (L2 or SL/FL) contexts, collocations have attracted considerable research attention over the last three decades (Barfield and Gyllstad 2009). They have been found to characterise overall proficiency, with empirical evidence demonstrating that there exists a clear relationship between knowledge of collocations - both receptive (Eyckmans 2009; Gyllstad 2007, 2009; Keshavarz and Salimi 2007; Nizonkiza 2011a) and productive (Bonk 2001; Eyckmans, Boers and Demecheleer 2004; Gitsaki 1999; Nizonkiza 2011b) - and proficiency. It is particularly striking that, although the studies were conducted on students from different backgrounds, using different approaches; they have shown that more proficient learners know more collocations. Additionally, collocations have been shown to perform an important function in academic texts (Gledhill 2000; Laufer and 
Waldman 2011; Nesselhauf 2005; Nizonkiza 2014). Nonetheless, they have been found to be problematic for EFL users even at an advanced learning stage (Howarth 1998; Laufer and Waldman 2011; Nesselhauf 2005). Even though collocations consisting of verb-noun combinations occur most frequently and are central to conveying meaning in a text (Gyllstad 2007), collocations involving adjectives and/or adverbs also perform a variety of rhetorical functions (Hinkel 2004) in academic texts. Quoting Huddleston and Pullum (2002), Hinkel (2004) maintains that adjectives and/or adverbs are frequent word forms and can be found in every sentence. With respect to adverbs Hinkel (2004) specifies that adverbs provide additional information while modifying verbs, adjectives, and other adverbs, which means that they are highly effective in communicating meaning.

However, research evidence seems to suggest that non-native speakers of English experience difficulty with adverbial markers in their academic texts (cf. Granger 1998; Hinkel 2003, 2004, 2005; Louw 2005). Hinkel (2004: 209) observes that non-native speakers frequently use intensifying adverbs (really, totally, extremely, etc.), but not hedging adverbs (possibly, perhaps, etc.) meant to limit the breadth of claims and generalisations used in academic texts. With respect to text type, adverbs seem to be playing an important role in academic texts. Hinkel (2004: 211-212) stresses the role adverbs play by linking them to verbs from Coxhead's (2000) Academic Word List (AWL) and showing how they add to the verbs' meanings, as in: quickly/immediately vs. slowly/eventually dissipate; firmly/solidly vs. weakly/temporarily establish; completely/greatly vs. sporadically/occasionally rely. These examples are good indications of where adverbs can affect the meaning being conveyed. Indeed, dissipating immediately and dissipating eventually clearly mean two different things. In this case, the adverbs play a focusing role, especially if the verbs or the entire sentence they modify are broad in meaning (Hinkel 2004).

Even though adverbs have been extensively investigated in EFL and ESL research in terms of their role/function in academic texts and their use by non-native speakers as opposed to native speakers, much less attention has been directed to adverbs in the adverb-verb combination. This neglect of adverb-verb collocations can be interpreted as if the combination is not prominently featuring in EFL writing in general or adverbs may not have an important function. The first argument seems more plausible to us, because the available literature on the role of adverbs in the academic writing of EFL students shows indeed that adverbs can have a considerable impact on the meaning of academic texts, notably because of their hedging or reinforcement function (Hinkel 2004, Louw 2005) or their persuasive function (Charles 2009). However, of the studies on collocations (described in section 2.2), only Martelli (2007) while inventorying collocation errors by EFL students attended to this type of collocation and found that adverb-verb combinations accounted for less than $4 \%$ of the total collocation errors. However, this does not mean, that participants had mastered this type of collocations. It could rather be the result of "an avoidance strategy: students, feeling unsure about how to combine a verb with an adverb in an appropriate manner, may choose to avoid the use of adverbs" to quote Martelli (2007: 57).

Based on the above-mentioned - adverbs being important, but less researched in the combination adverb-verb - the fundamental question worth raising here is the extent to which adverb-verb combinations may be problematic for non-native users of English when they produce academic texts. We aim to illuminate the use of adverb-verb collocations and therefore complement other studies focusing on other types of collocations and those examining adverbs 
in instances other than their collocational behaviour. Specifically, the following questions will be examined:

(i) To what extent do EFL junior researchers use adverb-verb collocations of academic vocabulary - pertaining to the Academic Word List (AWL) - in their free-written productions? Put differently, we aim to investigate if the verbs used in students' productions are correctly collocated (with adverbs).

(ii) To what extent do EFL junior researchers master adverb-verb collocations of academic vocabulary in a controlled setting?

To date, the most widely used academic vocabulary list for both research and teaching is Coxhead's (2000) AWL (cf. Coxhead 2011; Durrant 2009; Nation 2001; Paquot 2007; Schmitt and Schmitt 2005). It consists of a list of 570 word families compiled from a corpus of 3.5 million running words from a wide range of academic texts. A general observation is that academic words may be particularly difficult to learn for EFL students, because they do not occur frequently enough in general language contexts to be part of the common/general vocabulary that can be learned implicitly; nor are they specific enough to be taught as part of the technical vocabulary of the core subject courses (Coxhead 2000, Nation 2001). Since publication, until now, the AWL has been influential in testing, teaching and designing materials to teach for academic purposes (Coxhead 2011; Durrant 2014; Hyland and Tse 2007; Paquot 2007) and the "coverage figures of AWL over the various university-level corpora are consistently around 10\%" (Coxhead 2011: 357), the AWL will be the source for selecting the target verbs investigated in this study.

\section{Related literature}

\subsection{Definition of collocations}

The term 'collocation', which is "... used to refer to some kind of syntagmatic relation of words" (Nesselhauf 2005: 11) such as make a decision, bitter disappointment (Nesselhauf 2003: 223), has been approached in diverse ways (cf. Gyllstad 2007; Nesselhauf 2005). However, there are two prominent approaches commonly known as the "frequency-based" and the "phraseological" tradition (Barfield and Gyllstad 2009; Granger and Paquot 2008; Gyllstad 2007; Nesselhauf 2005). The former considers frequency as the main criterion for defining a collocation, while the latter dismisses frequency and considers the syntactic categories of collocations' constituents, their transparency in meaning, and the degree to which co-occurring words can be substituted by others as the defining criteria. In the frequency-based approach, frequently co-occurring words at a certain distance from each other constitute collocations (Halliday 1966; Sinclair 1991). This entails that statistics is used to determine whether or not co-occurring words are collocations; and Sinclair (1991) worked out a formula to be used to this end.

However, proponents of the phraseological tradition propose a scalar analysis of collocations (Gyllstad 2007; Nesselhauf 2005). For them, collocations lie on a scale ranging from free

\footnotetext{
${ }^{1}$ Coxhead (2011) made this observation based on studies that had investigated AWL distribution in academic texts from different fields over a period of 10 years prior to his work.
} 
combinations to pure idioms through restricted collocations and figurative idioms (Cowie 1998; Howarth 1998), which Howarth (1998: 28) defines in the following terms:

free combinations $[\ldots]$ consist of elements used in their literal senses and freely substitutable $[\ldots]$ Restricted collocations have one component $[\ldots]$ that is used in a specialized, often figurative sense only found in the context of a limited number of collocates. While figurative idioms have metaphorical meanings in terms of the whole and have a current literal interpretation, pure idioms have a unitary meaning that cannot be derived from the meanings of the components and are the most opaque and fixed category.

Howarth (1998: 28) distinguishes between free collocations (e.g. blow a trumpet), restrictive collocations (e.g. blow a fuse), figurative idioms (e.g. blow your own trumpet), and pure idioms (e.g. blow the gaff). To blow a trumpet is a free combination in which both blow and trumpet retain their literal meanings, and in combination they mean: playing this musical instrument (trumpet) by blowing into it. To blow a fuse is restrictive and means to lose your temper ${ }^{2}$ (informal). It is a metaphor with fuse alluding to the failure of an electrical circuit or engine as a result of overheating. In this case, it is the meaning of the noun fuse which dictates the verb(s) that can collocate with it; thus, making restrictions. This is not the case for blow your own trumpet - meaning talk openly and boastfully about your achievements - which is a fixed metaphorical expression. Its meaning is deciphered from the expression as a whole; entailing that the meaning of the expression cannot be assembled from the meanings of its constituents. This is even more so for the expression to blow the gaff, which is totally opaque in meaning to reveal or let out a plot or secret - and has no relationship with the meanings of each of its constituents.

It is worth noting; however, that some scholars adopting this approach exclude idioms and rather focus on restricted collocations, which for Howarth (1998) constitute the central area of the spectrum of the phenomenon of collocations and therefore are more significant than others. According to this scholar, restricted collocations constitute the biggest part and cause more problems to students and should thus be focused on more. The best classification of restricted collocations (operationalised through verb-noun collocations) to date comes from Howarth (Gyllstad 2007; Nesselhauf 2005). Howarth's (1998: 169-170) classification resulted in the following five subdivisions of collocations, "Level 1 being the most free and Level 5 being the most restricted".

- Level 1 allows freedom of the noun substitution, but has some restriction on the choice of the verb such as in adopt/accept/agree to a proposal, suggestion, recommendation, convention, plan, etc.

- Level 2 accepts some substitution of both nouns and verbs as appears in examples such as introduce/table/bring forward a bill/an amendment.

- Level 3 suggests some substitution of the verb with greater restriction on the choice of the noun, for example in pay/take heed.

- Level 4 places greater restriction on the choice of verb, with some substitution of the noun as in give the appearance/impression.

\footnotetext{
${ }^{2}$ The explanations of these expressions were taken from Siefring's (2004) Oxford dictionary of idioms.
} 
- Level 5 includes examples such as curry favour, which entails placing complete restriction on the choice of both nouns and verbs.

For descriptive purposes, Howarth (1998) suggests placing the cut-off point for defining collocations somewhere on the above scale. In his study, collocations are to be found between Level 2 and Level 5.

\subsection{Research on productive knowledge of collocations among EFL students}

The importance of collocations in EFL proficiency both in speaking and writing has led EFL researchers to trying to identify the problems collocations cause for EFL learners (cf. Barfield and Gyllstad 2009; Laufer and Waldman 2011; Nesselhauf 2005). Three main methodologies, i.e. "traditional error analysis of selected language samples, elicitation of collocations by various elicitation techniques, and finally, the analysis of large learner corpora, using commonly established corpus analysis techniques" have been used in the study of collocations (Laufer and Waldman 2011: 649). The third approach to studying collocations, corpus analysis, has allowed researchers to investigate collocations produced by EFL learners and draw conclusions from larger corpora (Barfield and Gyllstad 2009; Laufer and Waldman 2011). Studies that involved verb-noun collocations - the most widely investigated type of collocation - and combinations involving adverbs, which form part of the combination explored in this study, will be briefly reviewed in this section.

To date, the most comprehensive study that analysed collocations from students' written productions is Nesselhauf's (Gyllstad 2007; Laufer and Waldman 2011). Nesselhauf (2005) extracted 2000 verb-noun collocations from the Louvain International Corpus of Learner English (LICLE) ${ }^{3}$ German sub-corpus of approximately 154191 words. The results of her study indicate that a quarter of the collocations studied contained errors, with another third of them judged as wrong by some of the referees. Regarding the causes of errors, Nesselhauf (2005) found that about $50 \%$ of the errors were L1 related. A comparable study, which also investigated verb-noun collocations, was carried out by Laufer and Waldman (2011), who compiled a learner corpus called the Israeli Learner Corpus of Written English (ILCoWE) that contained approximately 300000 words of argumentative and descriptive essays (a total of 759 essays), written by native speakers of Hebrew. They selected the 220 most frequent nouns from both the native speaker's part of the LICLE, i.e. the Louvain Corpus of Native English Essays $(L O C N E S S)^{4}$, and their own learner corpus, and extracted related verb-noun collocations. Comparing EFL students' collocations with those of native speakers revealed that EFL students produced far fewer collocations than native speakers, who produced almost twice as many collocations as EFL students. Their analysis along the line of proficiency level of the participants (three groups were involved: basic, intermediate and advanced) showed that the use of collocations grows slowly and unevenly, with significant differences only emerging at

\footnotetext{
${ }^{3}$ The Louvain International Corpus of Learner English (LICLE) is one of the most important sources of EFL corpora that contains sub-corpora of European languages mainly, most of which are argumentative essays produced by higher intermediate to advanced students of English from several L1 backgrounds (Bulgarian, Chinese, Czech, Dutch, Finnish, French, German, Italian, Japanese, Norwegian, Polish, Russian, Spanish, Swedish, Tswana, Turkish). This information was accessed on 2 June 2013 from: https://www.uclouvain.be/encecl-icle.html.

${ }^{4}$ LOCNESS is a corpus of native English essays that consists of: British pupils' A level essays: 60209 words; British university students' essays: 95695 words; and American university students' essays: 168400 words. This information was accessed on 2 June 2013 from: https://www.uclouvain.be/en-cecl-icle.html.
} 
the advanced level. Furthermore, their findings about the causes of errors confirmed Nesselhauf's (2005), i.e. about 50\% of the errors were L1 related.

Verb-noun collocations have also been studied by Howarth (1998), who examined non-native speakers' essays of about 25000 words written by postgraduates coming from a large variety of L1-backgrounds. The essays were analysed and compared with native speaker counterparts whose texts were selected from two corpora, i.e. the Lancaster-Oslo-Bergen (LOB) corpus (58 000 words) and papers written by students at Leeds University (180 000 words). Howarth (1998) identified all the verb-noun collocations from both corpora, which he assigned to five different categories depending on the degree of semantic transparency. These were then grouped into three, i.e. free combinations, restricted collocations, and idioms. Howarth (1998) studied the category of restricted collocations and identified a total of 6500 collocations of which more than 5000 came from native speakers' texts while only around 1000 collocations were produced by non-native speakers. He found that native speakers employed about $50 \%$ more restricted collocations and idioms than EFL students, confirming the results from Laufer and Waldman (2011) and Nesselhauf (2005). Furthermore, while native speakers produced less than $1 \%$ of deviant collocations, non-native speakers produced more than $75 \%$ of unconventional collocations. For Howarth (1998), this is a clear indication that non-native speakers are not fully aware of the phenomenon of collocations.

This lack of familiarity with collocations among non-native speakers was confirmed by Granger (1998), who investigated the use of adverb-adjective combinations in native and non-native counterparts' essays. She identified all the -ly adverbs (amplifiers) from the essays consisting of 234514 words for native speakers and 251318 words for non-native speakers. The nonnative speakers were French L1 students of English at an advanced level and their texts formed a sub-corpus of the current LICLE. The native speakers' texts were retrieved from three corpora, i.e. the Louvain Essay Corpus, the International Corpus of English, and the LancasterOslo-Bergen Corpus. She observed a tendency of using amplifiers not as prefabricated patterns, but rather as "building bricks", and therefore reached the same conclusion as Howarth (1998) above: that non-native users are not entirely familiar with collocations. She also found that nonnative speakers significantly overused two amplifiers, completely and totally, while another amplifier, highly, was underused. Granger (1998) explained that completely and totally had direct equivalents in French; complètement and totallement, respectively. She also observed that highly, the underused amplifier, had a direct equivalent in French - hautement - but it is only used in formal settings. Obviously, as Granger observed, the direct relationship between French - the native language of the participants - and English caused both overuse and underuse. Therefore, she concluded that L1 transfer plays a role in collocation use; lending support to previous findings about collocation errors caused by language transfer, especially the learners' native languages.

Martelli's (2007) study has also confirmed the challenging nature of collocations. Martelli (2007) analysed 236 essays of approximately 141000 words and tagged all the collocation errors with reference to collocations dictionaries and native speakers' judgements, with the aim to classify and rank the errors Italian students of English make. Martelli (2007) identified the following categories: (i) wrong choice of adjectives in an adjective-noun combination (e.g. *heavy expectations rather than high/great expectations ${ }^{5}$ ); (ii) wrong choice of verb in a noun-

\footnotetext{
${ }^{5}$ Martelli (2007: 41) studied examples in the LICLE, Italian sub-corpus.
} 
verb combination (e.g. *requests grow up rather than requests increase/grow); (iii) wrong choice of verb in a verb-noun combination (e.g. *make influence rather than exercise/exert/have influence); (iv) wrong choice of adverb in an adverb-verb combination (e.g. *erroneously hurt rather than accidentally hurt); and (v) a whole expression that is wrong, i.e. where both constituents are wrong (e.g. * small criminality rather than petty crime). On comparing the types of collocations that were more problematic than others, Martelli (2007) found that verb-noun (in the $\mathrm{V}+\mathrm{N}$ combinations) collocations constituted half of the mistakes and therefore were more problematic. They were followed by adjective-noun and whole expression collocations, each totalling one fifth of the errors. Fewer errors came from verb-noun (in the $\mathrm{N}+\mathrm{V}$ combination) and adverb-verb collocations. While Martelli (2007) did not attempt to elucidate the causes of the verb-noun errors in the $\mathrm{N}+\mathrm{V}$ combinations, she suspected that avoidance strategies could account for the fact that fewer errors were produced in the adverb-verb combinations. As opposed to the studies described above, Martelli (2007) did not find much influence of L1 in the deviant collocations produced. However, she acknowledged that the category of whole expression was much affected by the learners' L1.

These studies provide a detailed overall picture of the use of collocations in free-written production in EFL contexts. However, we believe that more work needs to be done in order to gain more insight into the phenomenon of collocations, particularly the types that have been less studied.

\section{Methodology}

\subsection{Participants}

For the present study, students taking a writing course at a university in Belgium were invited to participate in a study to inform the content of their teaching programme. There were 35 respondents, who took part in the study voluntarily. All participants were non-native speakers of English (EFL) and were working on their PhD theses. They could thus be considered to at least have been introduced to if not acquainted with the academic register and the type of language required within their domain of study. The majority of the group had a European background, but there were also some Asian and African participants. The participants constituted a diverse population as they came from different faculties and institutes of the university. Of the 35 students who took part in the study, $63 \%$ were situated in the humanities (31\% of the group were language students, $23 \%$ political and social sciences, $9 \%$ applied economics and law) and 37\% from the Sciences (i.e. 20\% hold a degree in the sciences, 14\% in health care, and $3 \%$ in engineering).

\subsection{Instrument}

For this study, we used two types of instruments: an open writing task (small corpus) and a controlled completion test.

The first instrument was a small corpus of academic writing consisting of a total of 16660 words divided across 35 research abstracts totalling about 7800 words and 24 conclusions of about 8860 words. Both text types are typical for the humanities and the sciences. We anticipated that these two text components could be good representations of the use of adverbverb collocations in that the abstract, due to its restriction in scope (around 250 words), may 
have a low occurrence of adverbs, whereas the conclusion requires more hedging, and hence more adverbs, especially when referring to future work to be undertaken. The abstracts and conclusions were collected during a writing course in which the $\mathrm{PhD}$ students were enrolled. Students were encouraged to submit different academic texts, with the objective to support and enhance their publication output by providing them with individual feedback on their extracts. For comparative purposes, however, we only retained (for this study) abstracts and conclusions of students who participated in the completion task. It should also be noted that not everyone who submitted an abstract also submitted a conclusion, which is the reason why we collected 35 abstracts and 24 conclusions in all. This corpus was compiled in order to analyse adverbverb collocations of academic vocabulary from free-written productions.

The second instrument is a collocation test that was developed for the purpose of this study. It is a controlled completion test (see Appendix A). The test is controlled in the sense that items to test are predetermined and embedded in a restricted context. The test was modelled on Laufer and Nation's (1999: 37) controlled productive vocabulary level test that measures:

the ability to use a word when compelled to do so by a teacher or researcher, whether in an unconstrained context such as a sentence writing task, or in a constrained context such as a fill in task where a sentence context is provided and the missing target word has to be supplied.

In order to design the test, two sources, i.e. Coxhead's (2000) AWL and the Oxford collocations dictionary for students of English (Crowther et al. 2002), were used. The former was used for selecting target words (verbs), while the latter was used for selecting their collocations and the sentential contexts in which they were embedded. The verbs were selected using random sampling technique and a total of 30 verbs were retained. Their collocations were selected by looking up the target words (verbs) at their entry in the collocation dictionary that lists adverbs collocating with them. As the collocation dictionary does not always give example sentences for each combination, our principle was to retain the first adverb-verb combination where an example sentence was provided.

As Laufer and Nation (1999) suggest, the words investigated (adverbs) ${ }^{6}$ were deleted with the first two letters provided. Participants were instructed to supply them and an example was given (see Appendix A). Participants were awarded one point per correct answer and zero points per wrong or no answer; the test was marked out of 30.

\section{Analysis and results}

\subsection{Productive use of adverb-verb collocations by junior EFL researchers}

The first research question examined in this study is the extent to which EFL junior researchers use adverb-verb collocations at an academic level in their free-written productions. To start with free-productive knowledge of collocations, verbs involved in the adverb-verb combinations selected from abstracts and conclusions were checked against Nation's (2006) frequency bands and the AWL with the aim to find which ones belonged to the AWL. Out of the 69 verbs involved in the aforementioned combinations, $30.43 \%$ (21 out of 69$)$ were found

\footnotetext{
${ }^{6}$ Participants were specifically instructed that the word to supply was an adverb.
} 
to be included in the AWL (e.g. access, affect, communicate, enforce, establish, focus, etc.: see Appendix B). Combinations in which they appeared were analysed with reference to the Oxford collocations dictionary for students of English (Crowther et al. 2002) in order to see which ones were correctly collocated.

Two native speakers with a linguistic background (referees) were also involved in the rating of the combinations under study. The referees were asked to assist in deciding whether a combination could be acceptable as a collocation in case it was not found in the collocation dictionary. They were also asked to assess the ones that were judged as wrong according to the collocation dictionary. The combinations were judged on the following three-point scale: definitely not a collocation; acceptable combination, but not a collocation; and possible collocation. As it could be expected and as appears in their explanations, the referees used their native speaker's intuition in their judgements. The first referee explained his rating in the following terms:

"Essentially, in reviewing and responding to your items, I expressly avoided assessing their acceptability with reference to any written material and opted instead to run them through my own internal English word bank, housed (more or less safely) in my memory.

1. Those items that seemed to me to have a full collocative relationship, that is, that I would explain to a student as "typically going together", I marked as such. Their status as collocation in my responses is determined solely by the fact that they seem to me to be so! I use them this way; I expect them this way; I see their collocation as a set unit.

2. The ones that, in my view, combine acceptably but not as a collocation were assessed identically as above. In making that assessment, I asked myself if I "feel" these words as an organically linked unit. If not, then they were clearly not a collocation to me; but in reviewing their combination, I found it to be either communicatively (i.e., lexically) effective or else not to infringe [on] any grammatical rule.

3. A possible collocation for me was an item that was assessed identically as above (1 and 2) but for which I felt the acceptability of the collocation to be less satisfactory than in (1). No infringement of rules but a less harmonious combination. Comprehensible, yes; satisfactory, no".

He added, "I recognise that this is more intuition than fact", which was confirmed by the second referee who stated that "I tried to give quick, gut responses as a native speaker, rather than thought-out considerations as a linguist". This corresponds to what Hartwell (1985) calls the "grammar in our heads", which was summarised by Bean (2011: 70) in the following way: "[t]he internalized, preconscious knowledge of word arrangement and inflectional endings shared by all native speakers of a language". In order to measure the consistency in their judgements, the inter-rater reliability was calculated, which is $.840^{* *}$ for abstracts and $.809^{* *}$ for conclusions respectively (and significant at the 0.01 level, 2-tailed), and thus within the acceptable range, which should be from .7 upwards (Green 2013).

Results indicate that $47.61 \%$ (10 out of 21$)$ were used correctly (e.g. clearly communicate, mainly focus), while $52.38 \%$ (11 out of 21 ) could be considered as wrongly collocated (e.g. 
*initially affects, ${ }^{*}$ clearly diminishes $)$. These results answer the first research question pursued in this study about the performance of EFL junior researchers on adverb-verb collocations in their written productions. Overall, their performance may be considered unsatisfactory.

\subsection{Mastery of adverb-verb collocations from a controlled setting}

The second research question addressed in this study is the extent to which EFL junior researchers master adverb-verb collocations in a controlled setting. It was achieved by analysing the test scores from the completion task. Firstly, the reliability of the instrument was tested by computing Cronbach's Alpha, which turned out to be .6. Considering Pallant's (2007) suggestion (that Alpha should be at least .7), Cronbach's Alpha in this test falls slightly below the cut-off point. This could be accounted for by the items that could be either unsuitable for the level of the participants (too difficult or too easy) or inconsistent, and thus bad items, or it could be accounted for by the low number of participants or by the group that could be considered as homogeneous in terms of their familiarity with academic register. While this needs further elaboration (for instance, by involving a larger number of participants from clearly different levels of proficiency), we find the latter reason more plausible since all the participants were junior PhD students. Therefore, they could be assumed to have a comparable knowledge of the academic register after having been exposed to the discourse of their discipline for a minimum of five years and after having taken part in at least one academic writing programme during the course of their studies. Even though no attention was paid to the AWL during the writing course students take as part of the $\mathrm{PhD}$ programme, topics like academic register and style, false friends, phrasal and prepositional verbs and the like are incorporated in the course (see course materials of the Antwerp Doctoral School Programme for the course: Academic Writing).

The mean score of the test marked out of 30 was calculated as 20.66. This score is below Schmitt's suggested cut-off point. According to Schmitt (personal communication), quoted in Xing and Fulcher (2007), a particular word band or AWL is mastered if the score is $80 \%$ and above ${ }^{7}$.

For comparative purposes, the incorrect combinations according to the Oxford collocations dictionary for students of English (Crowther et al. 2002) were also judged by the referees on the three-point scale: definitely not a collocation; acceptable combination, but not a collocation; and possible collocation (see Appendix C). In total, we counted 97 (217 tokens ${ }^{8}$ ) deviant collocations, which were sent to the referees for assessment. After analysing the referees' judgements, we found that they were consistent in their rating, with an acceptable inter-rater reliability of $.831^{* *}$ (significant at the 0.01 level, 2-tailed).

More than half of the combinations, i.e. $58.7 \%$ were judged as definitely not a collocation (e.g. * synchronisedly analyse, *audaciously assume); $19.5 \%$ of the combinations were judged as acceptable combination, but not a collocation (e.g. simply analyse, symmetrically analyse); while $21.6 \%$ were judged as possible collocations (e.g. simultaneously analyse, concisely categorise). Based on the referees' judgements, we decided to also award the combinations that were rated as "possible collocations" and the completion task was graded again. The new

\footnotetext{
${ }^{7}$ We agree with Xing and Fulcher (2007: 184) that this cut-off point is not the result of any empirical evidence; yet, it remains the basis for determining vocabulary level especially for studies that use the Vocabulary Levels Test.

${ }^{8}$ The terms 'token' and 'type' are distinguished as follows: the same wrong combination could appear twice or more for instance and should not be counted as a different mistake: this is a type. If we count the total wrong combinations though, all the wrong combinations occurring twice/or more are counted: these are tokens.
} 
average score was 24.86 out of 30 and Cronbach's Alpha, which was also computed anew, was now .623. While Alpha remains almost the same, the overall score changes and rises slightly above Schmitt's cut-off point. Considering this new score, we can say that adverb-verb combinations had been mastered by junior EFL researchers in a controlled setting, which answers the second research question.

\section{Discussion}

The present study is an attempt to gauge junior researchers' use of collocations of the type adverb-verb combinations - especially those of verbs selected from the AWL - from the perspective of both free and controlled productive knowledge. This was achieved by analysing EFL users' academic texts - adverb-verbs from abstracts and conclusions - and engaging the same participants in a completion task.

The study's first aim, i.e. exploring the extent to which junior researchers use adverb-verb collocations (with verbs from the AWL), was achieved by analysing adverb-verb combinations in free-written productions. Results indicate that less than $50 \%$ of the adverb-verb collocations were correctly collocated. This finding is a clear indication that free-productive knowledge of collocations represents a high level of word knowledge and confirms the poor performance observed in previous studies. The latter indeed showed that EFL students are not sensitised enough to the use of collocations - verb-noun collocations in particular - when they produce academic texts (Granger 1998; Howarth 1998; Laufer and Waldman 2011; Nesselhauf 2005). At the same time this study extends this finding to another type of collocation. This finding also supports Martelli's (2007) observation that Italian students of English made less adverb-verb collocation errors in their essays because of avoidance strategies.

The second aim pursued in this study was to examine the extent to which junior researchers who are advanced EFL users master adverb-verb collocations in a controlled setting. This aim was achieved by analysing the participants' test scores. The results indicate that adverb-verb collocations from a controlled setting are not as problematic as adverb-verb collocations used in free production. These findings show that when EFL users are guided to the correct collocations, they perform well. Assuming Nation and Beglar (2007: 13) are correct in their observation that whichever 10 words from a particular frequency band are selected, they represent the entire frequency band, and all the other words are likely to be known to the same extent, we can claim that the present study shows that free-productive knowledge of adverbverb collocations lags behind controlled productive knowledge, even though not exactly the same words were investigated. This finding is a clear indication that free-productive knowledge represents a high level of word knowledge. Junior researchers had gotten a chance to use different strategies, including avoidance strategies, and could have thus used adverb-verb collocations they were certain of in their free productions as opposed to controlled productions in which they were forced to use predetermined adverb-verb collocations with the first two letters of the required words provided. However, they still made more mistakes in free productions. This finding supports Laufer and Paribakht's (1998) observation that receptive vocabulary is larger than controlled active vocabulary, which, in turn, is larger than free active vocabulary. This study's findings thus refine Laufer and Paribakht's (1998) findings to mean not vocabulary but collocations of the adverb-verb type. 
As a whole, the results of the present study show that correct use of adverb-verb collocations in free productions totals less than 50\% while performance in the same type of collocation use in a controlled setting is much better, but still just slightly above the cut-off point. For this reason, we repeat the call for teaching explicitly adverbs, on the one hand (see among others Charles 2009), and collocations on the other (cf. Boers, Eyckmans, Kappel, Stengers and Demecheleer 2006; Granger and Meunier 2008; Lewis 2000; Nattinger and DeCarrico 1992; Nesselhauf 2005; Nizonkiza and Van de Poel 2014; Nizonkiza, Van Dyk and Louw 2013; Ozaki 2011). We agree with Nizonkiza et al. (2013) that teaching collocations of words from academic vocabulary, such as the AWL, could contribute to improving the written output of EFL users. The collocations could be selected from a collocation dictionary such as the Oxford collocations dictionary for students of English (Crowther et al. 2002) if it is not for students from a subject-specific course for whom subject specific dictionaries might be more relevant, as Paquot (2007) proposes. We suggest adopting/adapting the collocation web model (Nizonkiza and Van de Poel 2014), which is an adaptation of McCarthy and O'Dell's (2005) model.

The collocation web model is production-oriented and could possibly be more beneficial for the learners more than a receptive approach (cf. Paquot 2007). This view is supported by Nation and Chung (2009) for whom teaching productively also has a direct positive influence on receptive knowledge growth. The collocation web model is thought to match Nation's (2001) psychological conditions for teaching any vocabulary item, i.e. noticing, retrieving, and generating. For Nizonkiza and Van de Poel (2014), Nation's conditions above constitute the theoretical foundation underpinning this approach. The collocation web model suggests placing the target word at the centre of a word web. The latter is linked to the collocates, which are placed in small circles by means of lines and Nizonkiza and Van de Poel (2014) suggest doing so following the syntactic nature (parts of speech) of the collocates. This way, students can notice the collocation constituents, the directions of the collocations - collocations to the right or to the left of the target word - as well as their syntactic categories (parts of speech). As a result, the creation and recreation of collocation webs in students' minds could facilitate their retention and retrieval (Handl 2009). The proposed exercises take the form of completion tasks where the target word is embedded in a minimal context and where the collocate has been deleted; but the first two letters may be provided. This is the format Laufer and Nation (1999) suggest with regard to testing controlled productive knowledge of vocabulary. This is teaching through cued recall, somewhat productive in nature, which is likely to result in more positive outcomes (Nizonkiza and Van de Poel 2014: 309). The exercises contribute to generating the collocates.

\section{Conclusion}

The present study explores free productive use of adverb-verb collocations in general and both their free and controlled productive knowledge in academic contexts (vocabulary operationalised through the AWL) among junior researchers using English as a foreign language for written communication. Results indicate that free adverb-verb productive knowledge of collocations from academic vocabulary is problematic for EFL users. However, in a controlled setting, adverbverb collocations from academic vocabulary appear to be somewhat less problematic. Given the limited scope of the corpus analysed in this study and the nature of the texts selected for analysis; however, we urge caution in generalising these results. These findings allow us to answer the initial research questions and are certainly indicative of the collocational behaviour of adverb- 
verb combinations of academic vocabulary among EFL junior researchers. We also believe that they could be complemented in follow-up studies.

Firstly, in line with our suggestion in the above section to attend to AWL verbs in a writing course, the only way to test whether or not intervention may result in improved use of adverbverb collocations or any other type of collocations judged relevant is by presenting the relevant collocations in a pre-/post-experimental design. A follow-up study of this nature may tell us more about the effect of specific interventions.

Secondly, a direct comparison between free productive and controlled productive knowledge of adverb-verb collocations from academic vocabulary could help form insights into the nature of productive knowledge. Instructing participants to use the verbs as used in the completion task and asking participants to generate adverbs that can be used with them in adverb-verb combinations can prove useful to this end. This could not only allow the drawing of a direct and straightforward comparison between free and controlled productive knowledge, but it could also contribute towards gaining useful insight into the construct of controlled productive knowledge. As defined by Laufer and Nation (1999), controlled productive knowledge does not make any distinction between unconstrained context, referred to as sentence writing tasks, and constrained context, referred to as fill-in-the-blank tasks where a sentence is provided, which might tap into different constructs.

Finally, a more robust analysis involving a larger corpus and especially other parts of academic texts could yield results that could potentially confirm or challenge the findings of the present study and therefore expand our knowledge of adverb-verb collocations in academic texts written by EFL junior researchers.

All in all, much has been said about the knowledge and use of different types of collocations. Based on the conclusions this study points to, we believe that focusing on academic vocabulary collocations during an academic writing course might help students write better research papers and communicate their research more fluently and more accurately.

\section{References}

Barfield, A. and H. Gyllstad (Eds). 2009. Researching collocations in another language. New York: Palgrave Macmillan.

Bean, J.C. 2011. ENGAGING IDEAS. The professor's guide to integrating writing, critical thinking, and active learning in the classroom. San Francisco: Jossey-Bass.

Boers, F., J. Eyckmans, J. Kappel, H. Stengers and M. Demecheleer. 2006. Formulaic sequences and perceived oral proficiency: Putting the Lexical Approach to the test. Language Teaching Research 10(3): 245-261.

Bonk, W.J. 2001. Testing ESL learners' knowledge of collocations. In T. Hudson and J.D. Brown (Eds). A focus on language test development: Expanding the language proficiency construct across a variety of tests. Honolulu: University of Hawaii Second Language Teaching and Curriculum Center. pp. 113-142. 
Charles, M. 2009. Stance, interaction and the rhetorical patterns of restrictive adverbs: Discourse roles of only, just, simply and merely. In M. Charles, D. Pecorari and S. Hunston (Eds). Academic writing: At the interface of corpus and discourse. New York: Continuum. pp. 152-169.

Cowie, A.P. (Ed). 1998. Phraseology. Theory, analysis, and applications. Oxford: Clarendon Press.

Coxhead, A. 2000. A new Academic Word List. TESOL Quarterly 34(2): 213-239.

Coxhead, A. 2011. The Academic Word List 10 years on: Research and teaching implications. TESOL Quarterly 45(2): 355-362.

Crowther, J., S. Dignen and D. Lea (Eds). 2002. Oxford collocations dictionary for students of English. Oxford: Oxford University Press.

Durrant, P. 2009. Investigating the viability of a collocation list for students of English for academic purposes. English for Specific Purposes 28(5): 157-169.

Durrant, P. 2014. Corpus frequency and second language learners' knowledge of collocations. International Journal of Corpus Linguistics 19(4): 443-477.

Eyckmans, J. 2009. Toward an assessment of learners' receptive and productive syntagmatic knowledge. In A. Barfield and H. Gyllstad (Eds). Researching collocations in another language. New York: Palgrave Macmillan. pp. 139-152.

Eyckmans, J., F. Boers and M. Demecheleer. 2004. The Deleted-Essentials Test: An effective and affective compromise. Available online: www.hltmag.co.uk/nov04/mart04.htm (Accessed 22 May 2013).

Gitsaki, C. 1999. Second language lexical acquisition: A study of the development of collocational knowledge. San Francisco: International Scholars Publications.

Gledhill, C.J. 2000. Collocations in science writing. Tubingen: Gunter Narr Verlag.

Granger, S. 1998. Prefabricated patterns in advanced EFL writing: Collocations and formulae. In A.P. Cowie (Ed). Phraseology: Theory, analysis and applications. Oxford: Oxford University Press. pp. 145-160.

Granger, S. and F. Meunier (Eds). 2008. Phraseology. An interdisciplinary perspective. Amsterdam: John Benjamins Publishing Company.

Granger, S. and M. Paquot. 2008. Disentangling the phraseological web. In S. Granger and F. Meunier (Eds). Phraseology. An interdisciplinary perspective. Amsterdam: John Benjamins Publishing Company. pp. 27-49.

Green, R. 2013. Statistical analyses for language testers. Basingstoke: Palgrave Mcmillan. 
Gyllstad, H. 2007. Testing English collocations. Unpublished PhD dissertation. Lund University. Available online: http://lup.lub.lu.se/search/record/599011 (Accessed 2 March 2013)

Gyllstad, H. 2009. Designing and evaluating tests of receptive collocation knowledge: COLLEX and COLLMATCH. In A. Barfield and H. Gyllstad (Eds). Researching collocations in another language. New York: Palgrave Macmillan. pp. 153-170.

Halliday, M. 1966. Lexis as a linguistic level. In C. Bazell, J. Catford, M. Halliday and R. Robins (Eds). In memory of J.R. Firth. London: Longman. pp. 148-162.

Handl, S. 2009.Towards collocational webs for presenting collocations in learners' dictionaries. In A. Barfield and H. Gyllstad (Eds). Researching collocations in another language. New York: Palgrave Macmillan. pp. 69-85.

Hartwell, P. 1985. Grammar, grammars, and the teaching of grammar. College English 47(2): $105-127$.

Hinkel, E. 2003. Adverbial markers and tone in L1 and L2 students' writing. Journal of Pragmatics 35(3): 1049-1068.

Hinkel, E. 2004. Teaching academic ESL writing: Techniques in vocabulary and grammar. Routledge: Taylor and Francis Group.

Hinkel, E. 2005. Hedging, inflating, and persuading in L2 academic writing. Applied Language Learning 15(1 and 2): 29-53.

Howarth, P. 1998. The phraseology of learners' academic writing. In A.P. Cowie (Ed). Phraseology: Theory, analysis and applications. Oxford: Oxford University Press. pp. 161-186.

Huddleston, R. and G. Pullum. 2002. The Cambridge grammar of the English language. Cambridge: Cambridge University Press.

Hyland, K. and P. Tse. 2007. Is there an “academic vocabulary"? TESOL Quarterly 41(2): 235-253.

Keshavarz, M.H. and H. Salimi. 2007. Collocational competence and cloze test performance: A study of Iranian EFL learners. International Journal of Applied Linguistics 17(1): 81-92.

Laufer, B. and I.S.P. Nation. 1999. A vocabulary size test of controlled productive ability. Language Testing 16(1): 33-51.

Laufer, B. and S. Paribakht. 1998. The relationship between passive and active vocabularies: Effects of language learning contexts. Language Learning 48(3): 365-391.

Laufer, B. and T. Waldman. 2011. Verb-noun collocations in second language writing: A corpus analysis of learners' English. Language Learning 61(2): 647-672.

Lewis, M. 2000. Teaching collocations: Further development in the Lexical Approach. Hove: Language Teaching Publications. 
Louw, H. 2005. Really too very much: Adverbial intensifiers in Black South African English. from the Corpus Linguistics Conference Series 1(1). Available online: http:///www.corpus. bham.ac.uk/pclc/ (Accessed 8 May 2013).

Martelli, A. 2007. Lexical collocations in learner English: A corpus-based approach. Alessandria: Edizioni dell'Orso.

McCarthy, M. and F. O’Dell. 2005. English collocations in use. Cambridge: Cambridge University Press.

Nation, I.S.P. 2001. Learning vocabulary in another language. Cambridge: Cambridge University Press.

Nation, I.S.P. 2006. How large a vocabulary is needed for reading and listening? Canadian Modern Language Review 63(1): 59-82.

Nation, I.S.P. and D. Beglar. 2007. A vocabulary size test. The Language Teacher 31(7): 9-13.

Nation, I.S.P. and T. Chung. 2009. Teaching and testing vocabulary. In: M.H. Long and C.J. Doughty (Eds). The handbook of language teaching. Malden: Wiley-Blackwell. pp. 543-559.

Nattinger, J.R. and J.S. DeCarrico 1992. Lexical phrases and language teaching. Oxford: Oxford University Press.

Nesselhauf, N. 2003. The use of collocations by advanced learners of English and some implications for teaching. Applied Linguistics 24(2): 223-242.

Nesselhauf, N. 2005. Collocations in a learner corpus. Amsterdam: John Benjamins Publishing Company.

Nizonkiza, D. 2011a. Relationship between lexical competence, collocational competence, and L2 proficiency. English Text Construction 4(1): 113-146

Nizonkiza, D. 2011 b. The relationship between controlled productive collocational competence and L2 proficiency. TTWiA 84/85: 29-37.

Nizonkiza, D. 2014. The relationship between productive knowledge of collocations and academic literacy among tertiary level learners. Journal for Language Teaching 48(1): 149-171.

Nizonkiza, D. and K. Van de Poel. 2014. Teachability of collocations: The role of word frequency counts. Southern African Linguistics and Applied Language Studies 32(1): 301-316.

Nizonkiza, D., T. Van Dyk and H. Louw. 2013. First-year university students' productive knowledge of collocations. Stellenbosch Papers in Linguistics 42: 165-181.

Ozaki, S. 2011. Teaching collocations effectively with the aid of L1. The Language Teacher 35(3): 37-40. 
Pallant, J. 2007. SPSS survival manual. Buckingham and Philadelphia: Open University Press.

Paquot, M. 2007. Towards a productively-oriented Academic Word List. In J. Walinski, K. Kredens and S. Gozdz-Roszkowski (Eds). Corpora and ICT in language studies. PALC 2005. Frankfurt am main: Peter Lang. pp. 127-140.

Schmitt, N. and D. Schmitt 2005. Focus on vocabulary: Mastering the Academic Word List. London: Longman.

Siefring, J. (Ed). 2004. Oxford dictionary of idioms. Oxford: Oxford University Press.

Sinclair, J. 1991. Corpus, concordance, collocation. Oxford: Oxford University Press.

Xing, P. and G. Fulcher. 2007. Reliability assessment for two versions of Vocabulary Levels Tests. System 35(2): 182-191.

\section{Acknowledgements}

We are grateful to our referee panel and panel of advisors Dr Daniel Van Olmen (Lancaster University), Dr David Owen (Autonomous University of Barcelona), Prof Frank Brisard (University of Antwerp), Prof Jessica Gasiorek (University of Hawaii at Manoa), Prof Jodi Mikalachki (University of Burundi), and Mr John Linnegar (edit and train, University of Antwerp). We are equally grateful to all the doctoral researchers who very enthusiastically took part in this study.

\section{Appendices}

Appendix A: Productive Vocabulary Test

Name:

Native language: Date:

Level of study (year): $\quad$ Start hour:

Faculty: $\quad$ End hour:

University:

Instruction: An adverb has been deleted in each of the sentences below, please supply it. The first

two letters have been provided to give you a hint.

Example: $\quad$ Her death affected him de............. Her death affected him deeply.

1. The results must be sy.................. analysed before we can draw any conclusions.

2. I au ................... assumed that you knew about this, otherwise I would have told you.

3. These factors can be con.................. categorised under the following three headings: school, home, society.

4. The minister commented fa................. on the proposal: He clearly liked it. 
5. His research has contributed en................. to our understanding of this disease, so we now can find a remedy.

6. The movement of the dot on the screen corresponds ex.................. with the movement of the control lever. This accuracy has never been seen before.

7. It is important to define these terms ac.................. in order to be able to work with them.

8. This study cl................. demonstrates that the play was written by Shakespeare.

9. They run $\mathrm{sp} \ldots \ldots \ldots \ldots \ldots \ldots \ldots$......... designed course for managers. Their tailor-made courses are fashionable.

10. His position in the organisation is now fi................. established and his career is guaranteed.

11. The evidence should be ca.................. evaluated before we can draw any conclusions.

12. The study focuses ex.................. on secondary schools. All the other factors are part of a follow-up study.

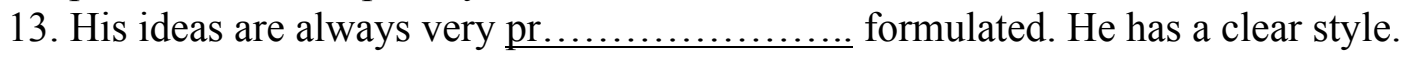

14. His question me.................. illustrates his ignorance of the subject.

15. Expense does not ne.................. indicate worth. It can mean many other things.

16. This hormone interacts $\mathrm{cl} \ldots \ldots \ldots \ldots \ldots \ldots$......... with other hormones in the body to generate new energy levels.

17. The term 'business' is here interpreted br. organisation in the public and private sectors.

to include all types of

18. The machine can pr................... locate radioactive material so it can be removed on the spot.

19. They will have the opportunity to participate ac.................. in the decisionmaking process. So, all stakeholders will be able to have their say.

20. Opportunities for learning occur $s p \ldots \ldots \ldots \ldots \ldots \ldots \ldots$ every day, so you just have to keep your eyes open for them.

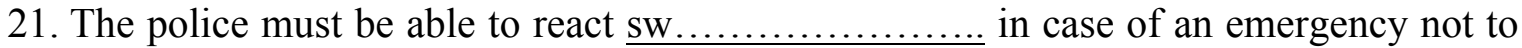
lose valuable time.

22. The use of these chemical products is st................. regulated in order to minimise any risks.

23. They relied en................... on these few weapons for their defence.

24. Many of the refugees ur................... require medical treatment in order to survive.

25. The government is considering new laws which will fu restrict people's access to firearms.

26. The winning entry will be selected ra................ by a computer.

27. She did not specify pr................... how many people were involved in the incident, so we don't know.

28. She had structured her argument very ca.................. and everyone felt reassured.

29. Skills cannot be transferred di.................. from trainer to trainee.

30. What can be found will in................. vary according to the area under study, so we have to keep an open mind. 


\section{Appendix B: Verbs from the AWL}

access, affect, analyse, communicate, conduct, consist, contribute, demonstrate, diminish, enforce, establish, focus, incorporate, occur, reject, respond, utilise

\section{Appendix C: Deviant collocations produced in the completion task rated by referees}

(Referees' judgements are presented as figures in the last column, which should be interpreted as follows: 1 = definitely not a collocation; 2 = acceptable combination, but not a collocation; $3=$ possible collocation)

\begin{tabular}{|c|c|c|c|}
\hline $\begin{array}{l}\text { Correct collocations as found } \\
\text { in the Oxford collocation } \\
\text { dictionary }\end{array}$ & Deviant collocations & Token & $\begin{array}{l}\text { Referees' } \\
\text { judgement }\end{array}$ \\
\hline 1. Systematically analyse & $\begin{array}{l}\text { 1. *Simply analyse } \\
\text { 2. *Simultaneously analyse } \\
\text { 3. *Symmetrically analyse } \\
\text { 4. *Synthetically analyse } \\
\text { 5. *Synchronisedly analyse } \\
\text { 6. *Synonymously analyse }\end{array}$ & $\begin{array}{l}1 \\
1 \\
1 \\
2 \\
2 \\
1\end{array}$ & $\begin{array}{l}2 \\
3 \\
2 \\
2 \\
1 \\
2\end{array}$ \\
\hline 2. Automatically assume & $\begin{array}{l}\text { 1.*Audaciously assume } \\
\text { 2.*Authentically assume }\end{array}$ & $\begin{array}{l}3 \\
2\end{array}$ & $\begin{array}{l}1 \\
1\end{array}$ \\
\hline 3. Conveniently categorise & $\begin{array}{l}\text { 1.* Concisely categorise } \\
\text { 2. }{ }^{*} \text { Consequently categorise } \\
\text { 3. } \text { Consecutively categorise } \\
\text { 4. }{ }^{*} \text { Consistently categorise } \\
5 .{ }^{*} \text { Consciously categorise } \\
\text { 6. }{ }^{*} \text { Conclusively categorise } \\
\text { 7.*Contentwise categorise } \\
\text { 8.*Constantly categorise } \\
\text { 9.* Conceptually categorise } \\
\text { 10.*Continuously categorise }\end{array}$ & $\begin{array}{l}5 \\
7 \\
2 \\
2 \\
1 \\
1 \\
1 \\
5 \\
1 \\
1\end{array}$ & $\begin{array}{l}3 \\
1 \\
3 \\
3 \\
3 \\
2 \\
3 \\
1 \\
1 \\
1 \\
3\end{array}$ \\
\hline 4. Comment favourably & $\begin{array}{l}\text { 1. *Fairly comment } \\
\text { 2.*Fantastically comment } \\
\text { 3. *Fabulously comment } \\
\text { 4. *Factually comment } \\
\text { 5. *Fanatically comment } \\
\text { 6. *Faithfully comment }\end{array}$ & $\begin{array}{l}3 \\
2 \\
2 \\
1 \\
1 \\
1\end{array}$ & $\begin{array}{l}1 \\
1 \\
1 \\
1 \\
1 \\
1 \\
2\end{array}$ \\
\hline 5. Contribute enormously & $\begin{array}{l}\text { 1. } * \text { Contribute endlessly } \\
2 . * \text { Contribute entirely }\end{array}$ & $\begin{array}{l}4 \\
1 \\
\end{array}$ & $\begin{array}{l}1 \\
1 \\
\end{array}$ \\
\hline 6. Correspond exactly & $\begin{array}{l}\text { 1.*Correspond explicitly } \\
2 . * \text { Correspond extremely } \\
\text { 3.*Correspond enormously } \\
\text { 4. *Correspond exponentially } \\
\text { 5. *Correspond exclusively } \\
\text { 6. *Correspond excellently } \\
\text { 7. }{ }^{*} \text { Correspond exhaustively }\end{array}$ & $\begin{array}{l}2 \\
2 \\
1 \\
3 \\
1 \\
1 \\
1\end{array}$ & \begin{tabular}{l|l}
3 & \\
1 & \\
1 & \\
1 & \\
3 & \\
2 & \\
1 &
\end{tabular} \\
\hline 7. Define accurately & 1. $*$ Define accordingly & 4 & 3 \\
\hline
\end{tabular}




\begin{tabular}{|c|c|c|c|}
\hline $\begin{array}{l}\text { Correct collocations as found } \\
\text { in the Oxford collocation } \\
\text { dictionary }\end{array}$ & Deviant collocations & Token & $\begin{array}{l}\text { Referees' } \\
\text { judgement }\end{array}$ \\
\hline 8. Clearly demonstrate & 1. ${ }^{*}$ Closely demonstrate & 1 & $\mathbf{1}$ \\
\hline $\begin{array}{l}\text { 9. Specially/specifically } \\
\text { designed }\end{array}$ & $\begin{array}{l}\text { 1. *Speedily design } \\
\text { 2. Spontaneously design } \\
\text { 3. Spotless design } \\
\text { 4. }{ }^{*} \text { Specialised design }\end{array}$ & $\begin{array}{l}1 \\
1 \\
1 \\
1\end{array}$ & $\begin{array}{l}1 \\
1 \\
1 \\
1\end{array}$ \\
\hline 10. Firmly established & $\begin{array}{l}\text { 1.*Finally establish } \\
\text { 2.*Fiercely establish }\end{array}$ & $\begin{array}{l}17 \\
2\end{array}$ & $\begin{array}{l}\mathbf{3} \\
\mathbf{1}\end{array}$ \\
\hline 11. Carefully evaluate & $\begin{array}{l}\text { 1. * Cautiously evaluate } \\
\text { 2. }{ }^{*} \text { Categorically evaluate }\end{array}$ & $\begin{array}{l}2 \\
1\end{array}$ & $\begin{array}{l}3 \\
2\end{array}$ \\
\hline 12. Focus exclusively on & $\begin{array}{l}\text { 1. *Focus exactly } \\
\text { 2. *Focus explicitly } \\
\text { 3. *Focus extensively } \\
\text { 4. *Focus exceptionally }\end{array}$ & $\begin{array}{l}2 \\
6 \\
1 \\
1\end{array}$ & $\begin{array}{l}\mathbf{1} \\
\mathbf{3} \\
\mathbf{3} \\
\mathbf{3}\end{array}$ \\
\hline 13. Properly formulate & $\begin{array}{l}\text { 1. *Pragmatically formulated } \\
\text { 2. *Precisely formulate } \\
\text { 3. *Practically formulate } \\
\text { 4. *Prudently formulated } \\
\text { 5. *Priory formulated } \\
\text { 6. Nothing (left blank) } \\
\text { 7. *Principally formulated } \\
\text { 8. *Profoundly formulated }\end{array}$ & $\begin{array}{l}1 \\
21 \\
2 \\
2 \\
1 \\
1 \\
1 \\
1\end{array}$ & $\begin{array}{l}2 \\
3 \\
1 \\
3 \\
1 \\
\text { NA } \\
2 \\
1\end{array}$ \\
\hline 14. Merely illustrate & $\begin{array}{l}\text { 1. *Meaningfully illustrate } \\
\text { 2. *Meticulously illustrate } \\
\text { 3. *Messily illustrate }\end{array}$ & $\begin{array}{l}1 \\
1 \\
1\end{array}$ & $\begin{array}{l}3 \\
2 \\
1\end{array}$ \\
\hline 15. Necessarily indicate & $\begin{array}{l}\text { 1.*Neatly indicate } \\
\text { 2. *Nearly indicate } \\
\text { 3. *Needlessly indicate }\end{array}$ & $\begin{array}{l}2 \\
1 \\
1\end{array}$ & $\begin{array}{l}\mathbf{1} \\
\mathbf{1} \\
\mathbf{1}\end{array}$ \\
\hline 16. Interact closely & $\begin{array}{l}\text { 1. } * \text { Interact clearly } \\
2 . * \text { Interact cleverly }\end{array}$ & $\begin{array}{l}9 \\
3\end{array}$ & $\begin{array}{l}3 \\
\mathbf{1}\end{array}$ \\
\hline 17. Interpret broadly & $\begin{array}{l}\text { 1. *Interpret briefly } \\
\text { 2. *Interpret bravely } \\
\text { 3. *Interpret brilliantly }\end{array}$ & $\begin{array}{l}3 \\
1 \\
1\end{array}$ & $\begin{array}{l}\mathbf{1} \\
\mathbf{1} \\
\mathbf{1}\end{array}$ \\
\hline 18. Precisely locate & $\begin{array}{l}\text { 1. *Probably locate } \\
\text { 2. *Practically locate } \\
\text { 3. *Primarily locate } \\
\text { 4. Properly locate }\end{array}$ & $\begin{array}{l}2 \\
1 \\
3 \\
1\end{array}$ & $\begin{array}{l}2 \\
1 \\
3 \\
1\end{array}$ \\
\hline 19. Participate actively & $\begin{array}{l}\text { 1. *Participate actually } \\
\text { 2. *Participate accordingly } \\
\text { 3. }{ }^{*} \text { Participate accurately }\end{array}$ & $\begin{array}{l}1 \\
4 \\
1\end{array}$ & $\begin{array}{l}1 \\
2 \\
2\end{array}$ \\
\hline 20. Occur spontaneously & $\begin{array}{l}\text { 1. } * \text { Occur speedily } \\
\text { 2. } \text { Occur specifically } \\
\text { 3. } \text { Occur practically }\end{array}$ & $\begin{array}{l}1 \\
2 \\
1\end{array}$ & $\begin{array}{l}1 \\
1 \\
2\end{array}$ \\
\hline 21. React swiftly & 1.Nothing (left blank) & 6 & NA \\
\hline
\end{tabular}




\begin{tabular}{|c|c|c|c|}
\hline $\begin{array}{l}\text { Correct collocations as found } \\
\text { in the Oxford collocation } \\
\text { dictionary }\end{array}$ & Deviant collocations & Token & $\begin{array}{l}\text { Referees' } \\
\text { judgement }\end{array}$ \\
\hline 22. Strictly regulate & $\begin{array}{l}\text { 1. *Strenuously regulate } \\
2 . * \text { Strongly regulate }\end{array}$ & $\begin{array}{l}1 \\
10\end{array}$ & $\begin{array}{l}2 \\
1\end{array}$ \\
\hline 23. Rely entirely & $\begin{array}{l}\text { 1.*Rely enormously } \\
\text { 2. *Rely encouragingly } \\
\text { 3. *Rely endlessly }\end{array}$ & $\begin{array}{l}6 \\
1 \\
1\end{array}$ & $\begin{array}{l}\mathbf{1} \\
\mathbf{1} \\
\mathbf{1}\end{array}$ \\
\hline 24. Urgently require & & & NA \\
\hline 25. Fully restrict & $\begin{array}{l}\text { 1. *Fundamentally restrict } \\
\text { 2. *Furthermore restrict } \\
\text { 3. *Functionary restrict } \\
\text { 4. }{ }^{*} \text { Fuzzily restrict }\end{array}$ & $\begin{array}{l}5 \\
1 \\
1 \\
1\end{array}$ & $\begin{array}{l}3 \\
1 \\
1 \\
1\end{array}$ \\
\hline 26. Randomly select & 1.*Rapidly select & 1 & 1 \\
\hline 27. Specify precisely & $\begin{array}{l}\text { 1. *Specify properly } \\
\text { 2. *Specify principally } \\
\text { 3. *Specify previously } \\
\text { 4. Specify priory }\end{array}$ & $\begin{array}{l}2 \\
1 \\
1 \\
1\end{array}$ & $\begin{array}{l}2 \\
1 \\
1 \\
1\end{array}$ \\
\hline 28. Structure carefully & $\begin{array}{l}\text { 1. *Structure calmly } \\
\text { 2. *Structure cautiously } \\
\text { 3. }{ }^{*} \text { Structure capably }\end{array}$ & $\begin{array}{l}3 \\
4 \\
1\end{array}$ & $\begin{array}{l}1 \\
2 \\
3\end{array}$ \\
\hline 29. Transfer directly & $\begin{array}{l}\text { 1. *Transfer dimly } \\
\text { 2.*Transfer differently } \\
\text { 3. *Transfer diagnostically }\end{array}$ & $\begin{array}{l}1 \\
1 \\
1\end{array}$ & $\begin{array}{l}1 \\
1 \\
1\end{array}$ \\
\hline 30. Inevitably/necessarily vary & $\begin{array}{l}\text { 1. *Invariably vary } \\
\text { 2. *Certainly vary } \\
\text { 4. *Possibly vary } \\
\text { 5. *Ultimately vary } \\
\text { 5. * Strongly vary } \\
\text { 6. *Definitely vary } \\
\text { 7. *Surely vary } \\
\text { 8. *Broadly vary } \\
\text { 9. *Evidently vary } \\
\text { 10. *Probably vary } \\
\text { 11. *Specifically vary } \\
\text { 12. *Highly vary } \\
\text { 13. *Completely vary } \\
\text { 14. *Largely vary } \\
\text { 15. *Potentially vary }\end{array}$ & $\begin{array}{l}1 \\
5 \\
2 \\
1 \\
2 \\
2 \\
1 \\
1 \\
3 \\
3 \\
1 \\
1 \\
1 \\
1 \\
1\end{array}$ & \begin{tabular}{l|l|}
3 \\
3 \\
3 \\
3 \\
3 \\
3 \\
3 \\
3 \\
3 \\
2 \\
3 \\
3 \\
3 \\
2 \\
1 \\
1 \\
1 \\
1 \\
1
\end{tabular} \\
\hline
\end{tabular}

